\title{
披裂部余㮃粘膜切除が奏功した成人発症の披裂部型喉頭軟弱症例
}

\author{
兵 頭 政 光・西 窪 加緒里・伊 藤 広 明
}

\section{A Case of Adult-Onset Arytenoid Type Laryngomalacia Successfully Treated with a Resection of Flaccid Arytenoid Mucosa}

\begin{abstract}
Masamitsu Hyodo, Kaori Nishikubo and Hiroaki Ito
Laryngomalacia is one of the most common diseases of laryngeal stenosis in newborns and infants. In contrast, adult-onset laryngomalacia cases are rare and the majority of them are classified as an epiglottic type. We report on a case of 20-year old female with arytenoid type laryngomalacia who presented with an intermittent inspiratory stridor after catching a cold. Her pulmonary function was normal; however, endoscopic examination showed an inward prolapse of the bilateral flaccid arytenoid mucosa during strained inspiration resulting in supraglottic stenosis. She underwent a resection of the flaccid mucosa bilaterally with the use of $\mathrm{CO}_{2}$ laser. Postoperatively, her inspiratory dyspnea had been successfully relieved for over a year. The rarity of adult-onset laryngomalacia may lead to overlooking the possibility of this disease. Physicians treating dyspneic patients should be aware of laryngomalacia even in adults and thorough endoscopic observation of the larynx should be mandatory.
\end{abstract}

Key words : laryngomalacia, adult-onset, inspiratory dyspnea, laser surgery

$$
\text { は じめ に }
$$

喉頭軟弱症（laryngomalacia）は脆弱な声門上部組織が 吸気時に喉頭内に引き込まれることで, 気道の狭窄を生じ る疾患である。多くは新生児ないし乳児に発症し, この時 期の小児の吸気性喘鳴の原因としては最も多いとされてい る ${ }^{1 \sim 3)}$ ，一方，本症が後天性に発症することはまれである が4)，それらでは喉頭蓋に病変を有することが多い，今回， 披裂部余剩粘膜が吸気時に喉頭内に陥入することで喘鳴を 生じた若年成人の喉頭軟弱症の非常に稀な 1 例を経験し た. 本症に対しては, 直達鏡下の披裂部余剩粘膜切除術が 奏功したので報告する.

\section{症 例 呈 示}

症例 : 20 歳, 女性

主訴：呼吸困難

現病歴: 生来, 呼吸障害等の自覚はなかった。 2010 年 1 月頃より咳が持続するため, 近医内科を受診、咳喘息と診 断されて, 投薬等の治療を受けた。 その後, 吸気時の呼吸 困難感を自覚し, 11 月頃には喘鳴も聴取するようになっ た。症状は咳嗽時や歩行時に強いが, 睡眠時にも息苦しさ がある。某病院耳鼻咽喉科へ紹介されたが，心因性疾患を 疑われ心療内科へ紹介され投薬を受けた。 しかし，その後 も症状の改善が得られず，他院内科での内視鏡検査で “披 裂部の肥大”を指摘されて, 2011 年 7 月に当科紹介受診し
た。

既往歴，家族歴：特記事項なし

初診時所見：深吸気時に喉頭部で喘鳴を聴取したが, 安静 時の $\mathrm{SpO}_{2}$ は $99 \%$ あっった。呼吸機能検査では 1 秒率は 85\%と正常であった，胸部 CTでも気管狭窄や肺野の異常 は認めなかった。喉頭内視鏡所見では, 声帯の麻痺や声門 下の狭窄などは認めず，随意的に咳払いをさせたりリラッ クスさせたりすると吸気時には声門はよく開大した（図 1a).しかし, 緊張すると喉頭前後長が短縮し, 吸気にと もなって両側披裂部内側の粘膜が喉頭内に引き込まれ, 声 門上部で気道狭窄を呈する所見を認めた（図 $1 \mathrm{~b})$. これら の所見より, 成人発症型の披裂部型喉頭軟弱症と診断し た。なお，あらためて行った問診でも吞酸や胸焼け等の症 状はなく, 内視鏡検査でも披裂部後方粘膜の浮腫性腫脹や
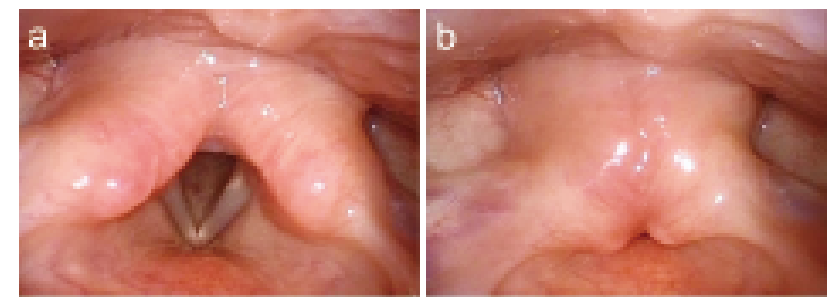

図 1 初診時喉頭所見 安静吸気時には声門は開大するが (a), 緊張時には喉頭 の前後長が短縮し吸気にともなって披裂部粘膜が喉頭内 に陥入する $(\mathrm{b})$. 


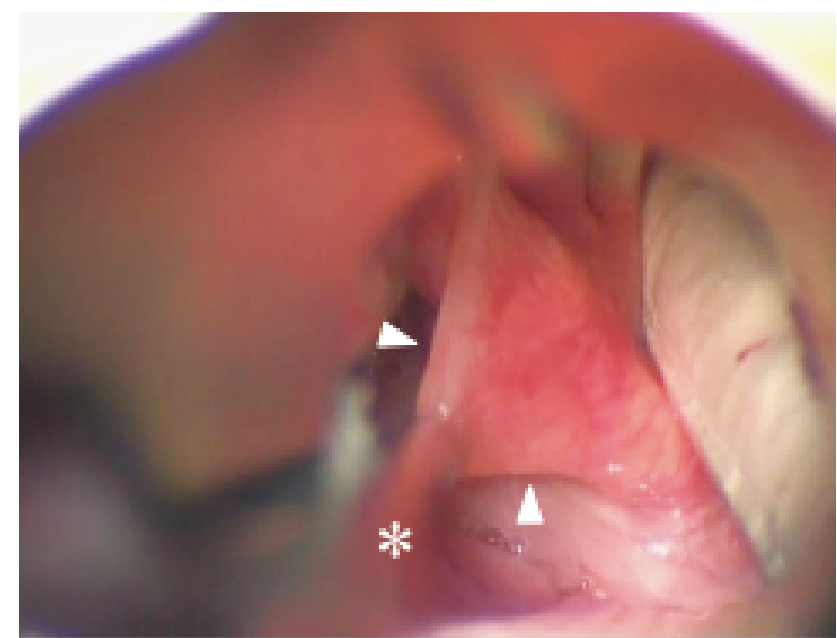

図 2 手術時所見

吸引管 $(*)$ で粘膜を吸引すると披裂部粘膜は過剩に伸 展する。
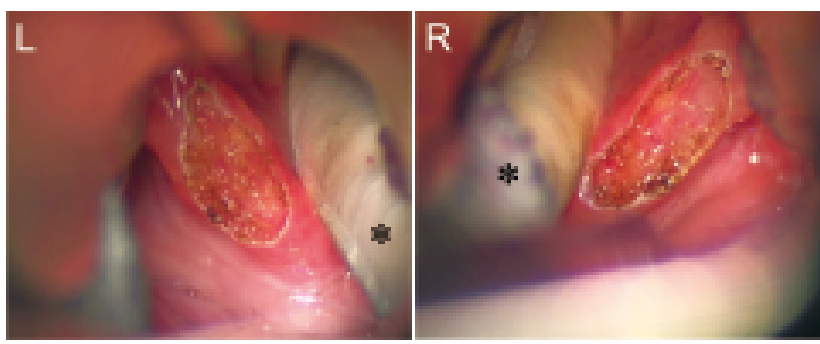

図 3 披裂部粘膜切除後の所見

両側の披裂部上面の粘膜を $\mathrm{CO}_{2}$ レーザーを用いて切除 した。 *は気管抻管チューブ.
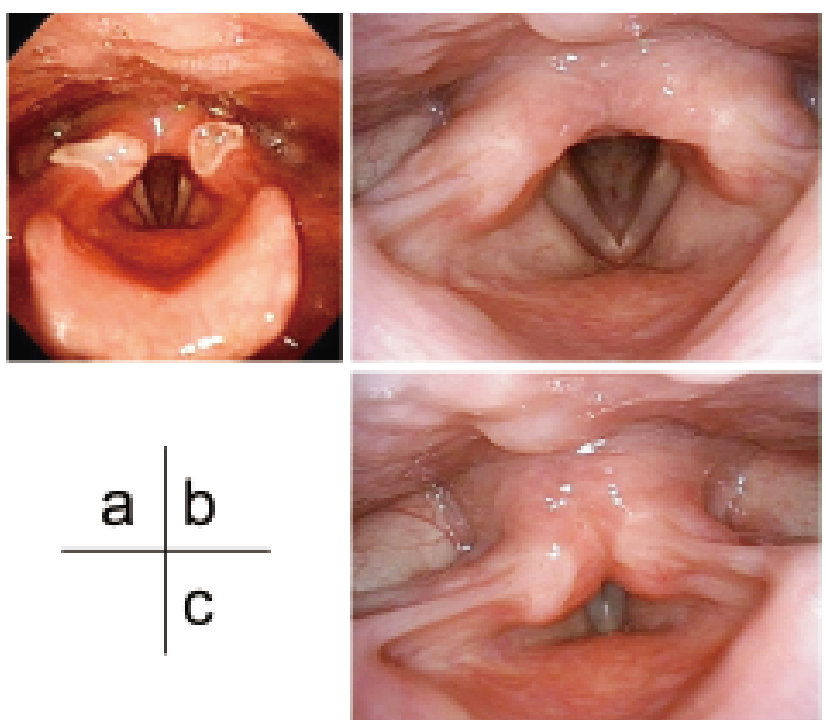

図 4 術後所見

1 週間後には切除部に白苔付着を認めるが (a), 1 カ月後 には同部は上皮化しており披裂部粘膜のたるみや吸気時 の喉頭内陥入は認めない (b). c は発声時.
披裂間粘膜の肥厚などの胃食道逆流症を疑わせる所見は認 めなかった

治療経過：2011年 9 月に全身麻酔下に両側披裂部余剩粘 膜切除術を施行した。喉頭直達鏡下に披裂部を展開し披裂 部粘膜を吸引管で吸引すると，粘膜には過剩な伸展性が あった（図 2)。そこで一側ずつ，披裂部上面の脆弱な粘膜 を $\mathrm{CO}_{2}$ レーザーにて切除した（図 3 )。この際に術後の瘏 痕拘縮による声帯運動障害を避けるために, 左右の創面が 連続しないように注意した

術翌日には自覚的にも呼吸困難は軽快した，1週間後に は粘膜切除部に白苔付着を認めたが (図 4a), 1 カ月後に は粘膜切除部も上皮化し, 吸気時の喉頭内への粘膜陥入は 認めなくなった（図 4b). 声帯の運動障害も認めない（図 4 b， c). 手術後, 約 1 年を経過した現在も吸気時の喘鳴や 呼吸困難はない

考察

喉頭軟弱症は，新生児期に気道狭窄をきたす先天性疾患 としては広く認知されている. 出生後まもなくあるいは数 週を経ておこる吸気性喘鳴として気付かれ，多くの例は 2 歳までに自然寛解する ${ }^{5)}$ 。喘鳴は啼泣時, 哺乳時, 仰臥位 などに強く，重症化すると睡眠時無呼吸，チアノーゼ，哺 乳障害, 身体発育障害などを呈する。病型分類に関して McSwiney ${ }^{6)}$ は，声門上部構造のどこが陥入するかに よって喉頭蓋型 (epiglottic type), 披裂喉頭蓋ひだ型 (aryepiglottic fold type), 披裂部型 (arytenoid type) に分類し た。さらに安岡ら ${ }^{2,7)}$ は、これに混合型 (combined type) を加えた 4 型への分類を提唱している。少においては披 裂部型がもっとも多いとされている ${ }^{5)}$.

一方，成人発症の喉頭軟弱症，あるいは後天性喉頭軟弱 症の報告例 ${ }^{8,9)}$ は本邦では散見されるのみである。しかし, 乳幼児の呼吸困難において本症の認識は高いが, 成人の呼 吸困難に対しては耳鼻咽喉科医においても喉頭軟弱症の認 識が少なく，本例のように見過ごされている例が少なくな い可能性がある。大出ら ${ }^{8)}$ は2 004 年までの本邦における 後天性喉頭軟弱症 6 例をまとめているが, 病型については いずれも喉頭蓋型であった。このように, 成人発症の喉頭 軟弱症には喉頭蓋型が多く，小児の例と異なり披裂部型の 報告は極めて稀である。これは成人では声門が乳幼児に比 較して広く，粘膜の喉頭内への陥入の影響が少ないためと 思われる。また，本例のような披裂部粘膜の陥入による呼 吸障害が，喉頭軟弱症の一病型であるとの認識が十分でな いことも考えられる.

後天性喉頭軟弱症は, 原因不明のこともあるが, 中枢神 経障害による喉頭笳の緊張低下や両側反回神経麻痺, 声門 上狭窄による吸気時陰圧による披裂部余㮃粘膜の形成，逆 流性食道炎による披裂部粘膜浮腫等が原因となることがあ $3^{8,9)}$ 。また, 安岡らは舌根囊胞や咽頭異物による声門上 部の狭窄に伴い, ベルヌーイ定理にて院圧が生じ声門上部 構造が喉頭内に陥入したと考えられる後天性喉頭軟弱症例 
を報告している ${ }^{2)}$ が，本例ではこれらの要因はなかった。 本例では感冒様症状を契機として発症したことより，従 前よりあった披裂部粘膜の脆弱性が喉頭粘膜の炎症によ る浮腫などの影響で増幅され，喘鳴が顥在化したものと 推測している。 さらに，吸気性呼吸困難のため努力性呼 吸となって喉頭腔の前後長が短縮し, 気道狭窄がさらに 増強したものと考えた。症状としては，運動時の吸気性 呼吸困難や，吸気時にのどにはりつく感じなどの訴えが 多い. Richter $~^{4)}$ も後天性喉頭軟弱症では普段の喘鳴は 稀だが，運動により症状が誘発されることが多いと報告 している. 本例でも運動時や緊張時などの努力性呼吸や 臥位などにともなって断続的な吸気性呼吸困難を呈して いたが，安静時には呼吸困難を自覚することはあまりな かった。このため, 安静時の $\mathrm{SpO}_{2}$ や呼気で計測する 1 秒 率などの呼吸機能は正常であり, 当初は喉頭軟弱症の診 断が困難であったものと考える。診断において詳細な問 診はもち万ん重要であるが, 大出ら ${ }^{8)}$ は頸部前屈や呼吸 負荷などを行うことの必要性を述べている.

本症の治療においては気道管理が重要となる。軽症〜 中等症の小览例では多くの例が 2 歳頃までに軽快すると され ${ }^{5)}$, 諸家の報告にあるように定期的なフォローでよい と考える。しかし, $\mathrm{SpO}_{2}$ の明らかな低下, 著しい閉塞性 睡眠時無呼吸, 肺性心による除脈・チアノーゼ, 哺乳 · 摂食障害による身体発育障害などがみられるような重症 例では外科的治療を考慮すべきである ${ }^{5,10,11)}$. 本例では $\mathrm{SpO}_{2}$ の低下や睡眠時無呼吸などの症状は認めなかった が，日常生活に扔ける支障が強かったことから手術適応 と判断した。手術法として披裂部型の例では披裂部余剩 粘膜のレーザー切除術の有効性が数多く報告されてお $\eta^{7.9 \sim 11)}$, 本例でもこの方法により症状の改善を得ること ができた。手術のポイントとしては，鉗子で余剩粘膜を 牽引しながら切除範囲を決定し余剩粘膜を取り残さない ことと, 術後の躲痕拘縮により声帯の開大運動が妨げら れないように披裂間部の粘膜は温存することであ $3^{5,11 \sim 13)}$. 一方, 喉頭蓋型では喉頭蓋の部分切除が行わ れる. 喉頭蓋の $1 / 2$ 程度の切除であれば誤嚥等の術後障 害もみられないとされている ${ }^{8)}$.

本例は若年成人女性であり, 呼吸困難の訴えに対して 当初は心因性疾患と診断されていた。症状出現時には努 力性呼吸がみられるなど心因的な要因の関与も否定はで きないが，成人の喉頭軟弱症に対する認識が十分でなかっ たことは否めない，比較的低侵襲の直達鏡下披裂部余剩 粘膜切除より速やかに症状の改善が得られたことからも， 本症に対する認識と適切な対応の必要性が示唆された。

\section{ま と め}

稀な成人発症の披裂部型喉頭軟弱症例を経験し, 喉頭 直達鏡下の披裂部余剩粘膜切除術により呼吸困難の改善 を得ることができた，本例に㧍ける発症機序や診断上の 問題点について考察を加えた.

\section{参 考 文 献}

1）守本倫子, 川城信子, 泰地秀信: 呼吸障害をきたす 喉頭疾患. 小児耳 $26: 24-26,2005$.

2) 安岡義人, 豊田 実: 喉頭軟弱症の取り扱い - 重 症例の検討 - . 喉頭 $21: 93-97,2009$.

3) Zoumalan R, Maddalozzo J, Holinger LD : Etiology of stridor in infants. Ann Otol Rhinol Laryngol 116 : 329-334, 2007.

4) Richter GT, Rutter MJ, deAlarcon A et al : Lateonset laryngomalacia : a variant of disease. Arch Otolaryngol Head Neck Surg 134 : 75-80, 2008.

5) 坂倉浩一, 安岡義人：喉頭軟弱症の病態と根治的治 療の必要性. JOHNS 19:1581-1584, 2003.

6) McSwiney PE, Cavanagh NPC, Languth P : Outcome in congenital strider (laryngomalacia). Arch Dis Child $52: 215-218,1977$.

7）安岡義人：喉頭軟弱症. JOHNS 27, 1951-1955, 2011.

8）大出茂典, 井上庸夫, 徳丸晶子ほか：後天性喉頭軟弱 症例。耳鼻臨床 97:43-46, 2004.

9）加藤 央, 木村美和子, 熊谷 譲ほか：披裂部余剩粘 膜により呼吸困難をきたした小览の 2 症例。日気食 会報 $60: 41-46,2009$ 。

10) Roger G, Denoyelle, Triglia JM et al : Severe laryngomalacia: surgical indications and results in $115 \mathrm{pa}-$ tients. Laryngoscope. 105 : 1111-1117, 1995.

11) 西窪加緒里, 兵頭政光: 外科的治療を要した喉頭軟 弱症の 2 例. 喉頭 $22: 25-29,2010$.

12 ) 山形和彦, 野本俊司, 兵頭政光ほか: 手術治療の奏功 した喉頭軟化症の 1 例。日気食会報 $44: 296-300$, 1993.

13) Senders CW, Navarrete EG : Laser supraglottoplasty for laryngomalacia:are specific anatomical defects more influential than associated anormalies on outcome?-. Int J Pediatr Otorhinolaryngol 57 : 235-244, 2001.

別刷請求先 广783-8505 高知県南国市岡豊町小蓮 高知大学医学部耳鼻咽喉科 兵頭政光 